\title{
Entrepreneurship Education - Does It Matter?
}

\author{
TorBjörn Nilsson ${ }^{1}$ \\ ${ }^{1}$ Entrepreneurship \& Innovation, Luleå University of Technology, SE-971 85 Luleå, Sweden \\ Correspondence: TorBjörn Nilsson, Entrepreneurship \& Innovation, Luleå University of Technology, SE-971 85 \\ Luleå, Sweden. Tel: 46-920-491-815. E-mail: torbjorn.nilsson@ltu.se
}

$\begin{array}{lcc}\text { Received: March 16, } 2012 & \text { Accepted: May 14, } 2012 & \text { Published: July 1, } 2012 \\ \text { doi:10.5539/ijbm.v7n13p40 } & \text { URL: http://dx.doi.org/10.5539/ijbm.v7n13p40 }\end{array}$

\begin{abstract}
This paper addresses an answer to the research question: does entrepreneurship education lead to establishment of new firms?. The research in the paper was based on a survey with a questionnaire and the questionnaire was sent to two different groups of respondents, a Respond group (who had completed an entrepreneurship education) and a Control group (who had not passed an entrepreneurship education). The respondents had the same educational background aside from the entrepreneurship education. In addition to the survey three (short) telephone interviews were performed. The paper shows that individuals attending entrepreneurship education are more likely to establish firms, to establish several firms and to create larger firms, compared to the Control group. To sum up the answer to the research question based on results is that entrepreneurship education does indeed lead to the establishment of new firms.
\end{abstract}

Keywords: entrepreneurship education, new firms, establishment of new firms, small firms

\section{Introduction}

When discussing small firms and business enterprises it is unavoidable to talk about the formation of new firms. In Sweden, as in many other countries the formation of new firms is dependent upon the citizens' fundamental approach and knowledge about this phenomenon. Some people who establish new firms are socialized into an entrepreneurial culture by for example associated persons and their firms, which tend to make the establishment process easier. This social heritage or entrepreneurial culture is consequently an important factor in the establishment of new firms and also in the amount of new firms. Other people who establish new firms have never been a part of an entrepreneurial culture except as employees. Evidently, these two groups have different prerequisites for self-employment and also probably have different opinions about the opportunities and threats associated with self-employment and the establishment of new firms, also called entrepreneurial thinking or entrepreneurial intentions.

$\mathrm{Wu}$ and $\mathrm{Wu}(2008$, p. 754) write that "Entrepreneurial intentions.....is a driving force of the entrepreneurial activity". In Nabi, Holden and Walmsley's (2010 p. 538) discussion of entrepreneurial intentions they write "In broad terms, entrepreneurial intentions can be defined as a conscious awareness and conviction by an individual that they intend to set up a new business venture and plan to do so in the future". In the same spirit Johannisson, Madsén and Wallentin (2000, p. 34), write that entrepreneurial thinking can be defined as "when a person in her way of thinking focus business enterprise, is fertile in ideas, is willing to discuss her ideas with other persons, is active and concentrate on realizing what has been determined".

When new firms are established different entry barriers occur and can take place within the individuals themselves due to a lack of entrepreneurial thinking or entrepreneurial intentions, however entry barriers can also arise from external factors such as the type of firm established, the type of industry where the new firm is established or the entrepreneurial culture in the surrounding society. In addition entry barriers can also be associated with markets, technical development, resources, and the internal organization of the new firm. If the establishment of new firms is to be successful then the entry barriers have to be mastered.

\section{Challenges in Entrepreneurship Education}

There are several ways to reduce problems associated with the establishment of new firms, such as the influence of entry barriers, and thereby increase the amount of new firms. One way to reduce these problems is to teach individuals in entrepreneurship and business enterprising; however, the research field has conflicting perspectives 
as to whether it is possible to teach entrepreneurship and business enterprising or not. An interesting and important question, therefore: is as follows: is it possible to educate people to be more entrepreneurial and more interested in establishing new firms? The question is disputed, and in research we can find two answers - yes and no, (see, e.g., Jack and Anderson, 1998; Henry, Hill \& Leitch, 2005). Simply put, the affirmative answers are connected to "science", and the negative answers are connected to "art". This refers to the problems involved teaching people in entrepreneurship. Some things are assumed to be easy to teach, such as "science" however "art" is not easy to teach.

The no answers are connected to the more creative and an innovative part in the entrepreneurial process and this perspective on entrepreneurship as an art is related to aspects that lie within individuals' characteristics therefore, it can be difficult to teach (Henry et al., 2005). Consequently, such perspective means that entrepreneurship education is pointless as an attempt to increase peoples' establishing of new firms. Some researchers underscore the importance of passion for running a business, and therefore question whether it is possible to educate in such way that this passion can emerge, while other researchers argue that such passion can be strengthened by entrepreneurship education (Souitaris, Zerbinati \& Al-Lahman, 2007; Cox, Mueller \& Moss, 2002; Hansemark, 1998).

The yes answers are connected to more traditional techniques which are necessary if you are going to run a firm such as accounting, budgeting and marketing; Drucker (1985) writes therefore, "The entrepreneurial mystique? It's not magic, it's not mysterious, and it has nothing to do with genes. It's a discipline. And, like any discipline, it can be learned." Similarly, Kuratko (2003, p. 11) writes,"...entrepreneurship, or certain facets of it, can be taught". Also, Robinson, Stimpson, Huefner \& Hunt (1991) like Mitra and Matlay (2004) argue that entrepreneurial skills can be learned. These statements can be understood as being representative of a scientific perspective on entrepreneurship, which claims that it is possible to educate individuals in entrepreneurship and business enterprising. In other words, we can connect these standpoints to the "yes-answers" and, from such a perspective; entrepreneurship education would increase the number of established firms.

The yes and no answers can also be seen as an effect of the Schumpeterian or Kirznerian view of entrepreneurship respectively. "If entrepreneurship is equated with the causing of economic disequilibrium, as per the Schumpeterian literature, then one can argue that entrepreneurs tend to be born, rather than made" (Dana, 2001, $\mathrm{p}$. 405). In other words, if you have this view of entrepreneurship, then it is impossible to teach entrepreneurship. There exists on the other hand, a contrasting view on teaching entrepreneurship "if one links entrepreneurship to Kirznerian literature, where the entrepreneur simply identifies opportunities for profit without actually creating them, then it could equally be argued that entrepreneurs are made and that entrepreneurship itself can be taught" (De Faoite, Henry, Johnston \& van der Sijde, 2003, p. 432). This means that entrepreneurship education needs to focus on how to identify opportunities, how to commercialize these opportunities, and then how to run an established firm.

Apparently, there exist two "schools" in teaching entrepreneurship - a "yes-school" (i.e. entrepreneurship is teachable) and a "no-school" (i.e. entrepreneurship is non-teachable) - and thus we have to accept that there are aspects of entrepreneurship that can be taught and others that cannot.

\section{The Problem and the Purpose}

According to the discussion above, this paper focuses on the "yes-school" which means that it is possible to teach entrepreneurship; however this is only one side of the coin. Another side of the coin is represented by the question "Does entrepreneurship education matter?". Different researchers, however, emphasize the difficulties of evaluating the benefit or the importance of teaching entrepreneurship, see e.g., McMullan and Gillin (2001). Cox et al. (2002, p. 230) write "much of the entrepreneurship research to date has not provided empirical support for the claim that completion of formal courses in entrepreneurship and small business management increases the likelihood that an individual will start a business". Along this line of thought, Matlay (2005, p. 672) adds "the actual contribution that such courses have on entrepreneurial activity remains unclear".

Conclusions like these are presumably based on different problems in studying entrepreneurship education and its outcomes. The problems mentioned above are in some way connected to time, more specifically, the time delay from the end of an entrepreneurship education until a possible business start of a business (see, e.g. Cox et al., 2002 and Matlay, 2005). The time delay can be long and, in such cases, it can be difficult to determine exactly why an individual has established a new firm. Was the individual influenced by the entrepreneurship education or were there other factors that inspired individual to establish a new firm?

The time delay can be described as a firm's development process. Nilsson (1997) illustrates this process as consisting of three phases: a creative phase, a setting-up phase and an operational phase (Figure 1). 


Creative phase $\quad$ Setting-up phase

Figure 1. Firm development process

Source: Nilsson (1997, p. 12)

The development process comprises the process that precedes a firms establishment and can be characterised as a process of moving "from concept to company". It should, however, be pointed out that it is the individual, the prospective founder of a firm, who is the focus during the creative phase, as at this time, no firm exists in the true sense. The firm exists purely as a mental picture in the mind of its prospective founder. It is not until a firm has actually been founded and established that we can retrospectively see it as a firm and think of as being in its creative phase. This in turn means that it is not until the transition from the creative to the setting-up phase, that is at point A in Figure 1, that the firm is started. The setting- up phase comprises such activities as commercialising a new product, which means that the founder of the firm must contact potential customers, organise production and distribution. By point $\mathrm{B}$, the firm is set up, which means that customers define the firm as existing. Then begins the operational phase that involves the on-going commercial activities.

The above described-development process presents a better picture of the course of events than the one where the establishment of a new firm is seen as a single episode (e.g. point A in Figure 1). This latter description is too static and does not consider the time delay that is inherent in a firm's development process. As a result, the static view of a firm's development process is not useful when the purpose is to assess whether individuals who have passed an entrepreneurship education are more willing to establish a firm than those who have not. In this paper, it is therefore natural to choose the process view of a firm's development process (Figure 1). A process like this is very complex and dynamic; there are many different factors, including factors connected to the person, sociological factors, and factors connected to the environment - all of which have to interact if the development process is to succeed. One way to facilitate this interaction and consequently make it possible for a firm's development process to succeed is to acquire different kinds of entrepreneurship education. The question remains, though, "Does it matter?". It is in my opinion both desirable and important to clarify the effects of entrepreneurship educations on individuals' willingness to establish new firms and, by extension, the actually establishment of new firms. The purpose of this paper is then to answer the question does entrepreneurship education lead to establishment of new firms?

To gain an understanding of the impact/result of entrepreneurship education, I have conducted a search in three databases (Ebsco, Emerald and JSTOR), using several the search words - entrepreneurship, education, impact and result - in various combinations. I have also completed a review of 1207 articles from five selected scientific journals (Journal of Small Business Management; Entrepreneurship Theory and Practice, Journal of Business Venturing, Journal of Small Business and Enterprise Development, Education + Training) during the period from 2006 to 2011. The result of the database search and review of the articles shows that there was a dearth of articles discussing the result/impact of teaching entrepreneurship on the establishment of new firms! In other words, research in this field is very poor.

\section{Method}

To answer the question "does entrepreneurship education lead to, the establishment of new firms?" one must perform both a quantitative and a qualitative study, so that entrepreneurial activity, thinking and intention are explored and explained properly. As a first step I conducted a quantitative study which is presented in this paper and the meaning of this paper was to describe and explore if entrepreneurship education leads to, the establishment of new firms. According to the result of the database search and review of the articles I found it important to clarify the impact that entrepreneurship education can have on the establishment of new firms and to increase the knowledge in this research field. In a second, qualitative study, I will study and answer the question why and how entrepreneurship education leads to greater entrepreneurial activity. The research in the present paper was based on a survey with a questionnaire supplemented with three short telephone interviews.

Over a period of ten years (1995-2005) an entrepreneurship education called "Entrepreneurship and new firms' formation" was carried out at Luleå University of Technology (LTU). The education embraced 15 ECT (European Credit Transfer System) during one semester. To answer the question "does entrepreneurship education lead to the 
establishment of new firms?" it was necessary to use two groups of respondents, one group consisted of individuals who had passed an entrepreneurship education ("Entrepreneurship and new firms' formation"), the Respond group and another group consisted of those who had not, the Control group. The respondent sample was comprised of former students at LTU.

As named above the survey was sent to two different groups of respondents: 1) a Respond group comprised of all students who had passed their ordinary program (Master of Business Administration and Economics or Master of Science in Engineering) and also had completed their entrepreneurship education ("Entrepreneurship and new firms' formation") at LTU, this means that the census was investigated; and 2) a Control group, which included a sample of those students who had not attended the course in entrepreneurship at the University but had passed their ordinary program (Master of Business Administration and Economics or Master of Science in Engineering). The respondents had, in other words, the same educational background aside from the entrepreneurship education. To examine the time delay in a firm's development process, it was essential to use a longitudinal approach using these two groups of respondents. To fulfil this demand the respondents were chosen from the period of 1995-2005, i.e. when the entrepreneurship education was carried out. This procedure is supported by Matlay (2005) and Garavan and O' Cinnéide (1994, p. 5), who writes 'Longitudinal research designs, using control groups to compare participants with individuals who did not have entrepreneurship education experience, are needed to examine the lasting effects of entrepreneurship education and training interventions."

The underlying suggestion was that this way of working made it possible to discover divergences in terms amount of established new firms between those respondents who had passed an entrepreneurship education and those who had not.

The survey consisted of 18 questions divided into the following areas:

1) background information

2) information on established new firms

3) information on entrepreneurial intention.

Table 1. Sample size and response rate

\begin{tabular}{lccc}
\hline & $\begin{array}{c}\text { Sample size } \\
\text { (number) }\end{array}$ & $\begin{array}{c}\text { Responses } \\
\text { (number) }\end{array}$ & Response rate (percent) \\
\hline Respond group & 117 & 77 & 66 \\
Control group & 141 & 88 & 62 \\
Total & 258 & 165 & 64 \\
\hline
\end{tabular}

After a three-wave mailing 165 valid questionnaires were obtained from a valid sample of 258 persons (Table 1), which corresponded to a response rate of $64 \%$. The respondents' answers in the questionnaire were coded in SPSS 17.0 (Statistical Package for the Social Sciences).

To answer the question "does entrepreneurship education lead to the establishment new firms?" it is important to discuss operationalization of the concepts in the survey. The establishment of a new firm was not seen as a single episode (Figure 1) in the present study; it was instead seen as a process where both survival and growth of the firm were important parts. In other words to be seen as an established firm the firm must have survived some years. In this study the firms must have survived at least five years, i.e. five years from the start (point A in figure 1) until the questionnaire was answered. This means that an established firm is an existing firm characterized of on-going commercial activities. The establishment of a firm have taken a further step forward; the establishment is even more strengthened if the firm has grown from the start until the questionnaire was answered. In the present study the growth is measured as the change in the number of employees and the change of the total turnover among the established firms.

Different authors, for example $\mathrm{Wu}$ and $\mathrm{Wu}$ (2008), discuss entrepreneurial intention as a driving force of the entrepreneurial activity. The entrepreneurial intention is in other words a base for the entrepreneurial activity and will consequently influence the establishment of new firms. If there is a lack of entrepreneurial intention there will be a deficit in the amount of established new firms. The entrepreneurial intention is in this study regarded as the respondents view on this phenomenon, i.e. does the respondents think of the entrepreneurial intention as something you are born with or is it something you can learn and develop? In addition to the survey, three (short) 
telephone interviews were performed to enhance our understanding of the respondents' entrepreneurial intention. Three telephone interviews are not enough to provide us with valid knowledge of entrepreneurial intention, but they can hopefully shed some light on the potential effects of an entrepreneurship education on individuals' decision to establish a new firm. In other words, the purpose of the telephone interviews was to broaden our knowledge of entrepreneurial intention among the respondents who had established a new firm. From the Respond group, the three respondents were chosen at random from those who had answered the questionnaire and had established a new firm. Only the following three questions were used:

1) Did you have an intention to establish a new firm when you began the entrepreneurship education?

2) Would you have established the new firm even if you had not entered and passed the entrepreneurship education?

3) Did the entrepreneurship education inspire you to establish a new firm?

The entrepreneurial activity is regarded as the number of established new firms and the number of persons who were running two or more firms.

Table 2. Operationalization of concepts in the survey

\begin{tabular}{|c|c|c|c|}
\hline $\begin{array}{l}\text { Entrepreneurial } \\
\text { intention }\end{array}$ & $\begin{array}{l}\text { Establishment of new } \\
\text { firms }\end{array}$ & $\begin{array}{l}\text { Strengthened } \\
\text { establishment of new } \\
\text { firms }\end{array}$ & $\begin{array}{l}\text { Entrepreneurial } \\
\text { activity }\end{array}$ \\
\hline \multirow{2}{*}{$\begin{array}{l}\text { The respondents } \\
\text { view on } \\
\text { entrepreneurial } \\
\text { intention. }\end{array}$} & $\begin{array}{l}\text { Number of firms } \\
\text { which had survived at } \\
\text { least five years }\end{array}$ & $\begin{array}{l}\text { Growth in the } \\
\text { turnover } \\
\text { established new firms }\end{array}$ & $\begin{array}{l}\text { Number } \text { of } \\
\text { established new } \\
\text { firms }\end{array}$ \\
\hline & & $\begin{array}{l}\text { Growth in the number } \\
\text { of employees in } \\
\text { established new firms }\end{array}$ & $\begin{array}{lr}\text { Number } & \text { of } \\
\text { persons } & \text { who } \\
\text { were running } \\
\text { two or more } \\
\text { firms }\end{array}$ \\
\hline
\end{tabular}

Comparisons between the Respond group and the Control group were made concerning operationalized concepts. These comparisons were made to find an answer to the overall purpose of the study. In other words, do those who have participated in entrepreneurship education have a higher entrepreneurial activity and do they establish new firms to a higher extent than those who have not?

\subsection{Perceived Methodological Problems}

Evaluating the results of an entrepreneurship education can be very difficult due to the intrinsic problems such as time delay and self-selection bias. The time delay has been overcome by using a longitudinal study approach with a control group to provide an understanding of the long-term effects of the studied entrepreneurship education. A longitudinal research approach, as described earlier, is necessary to examine the lasting effects of entrepreneurship education (Garavan and O' Cinneide, 1994). A more pressing problem is the one connected with self-selection. By definition, those individuals who voluntarily participated in the entrepreneurship education self selected themselves to the education: this self-selection can, when answering the question "does entrepreneurship education lead to the establishment of new firms?" lead to inaccurate assessments being produced. To reduce the problem of self-selection it was important to ensure that the highest possible response rate to the questionnaire administered was obtained. After a three-wave mailing the total response rate was $64 \%$ (Respond group $66 \%$ and Control group $62 \%$ ). This implies that the study obtained a view of the respondent populations (Respond group and Control group) that was as representative as possible. The Respond group and the Control group were also matched to each other so that the respondents had the same educational background aside from the entrepreneurship education.

\section{Empirical Findings}

Most of established firms, both in the Respond group and the Control group, can be characterised as service companies. Manufacturing firms are therefore very rare among the established firms. 


\subsection{Entrepreneurial Intention}

A person's entrepreneurial intentions or entrepreneurial thinking will make it easier to establish a new firm and it is assumed to be an important factor in the establishment process (Nabi et al., 2010; Wu and Wu, 2008; Johannisson et al., 2000). The present study shows that those who have not attended the entrepreneurship education (the Control group) regard the entrepreneurial intentions as an inheritance, unlike those who have passed the entrepreneurship education (the Respond group) who think that one can create one's destiny by oneself. The telephone interviews (Table 3) show that there is a kind of entrepreneurial intention among the respondents since all three had an intention to start a firm when they entered their entrepreneurship education. We can also see that the education inspired these three persons to establish new firms as discussed by Souitaris et al., (2006).

Table 3. Results from the telephone interviews

\begin{tabular}{lccc}
\hline & $\begin{array}{c}\text { 1. Intention to establish a } \\
\text { firm? }\end{array}$ & $\begin{array}{c}\text { 2. Established a new firm } \\
\text { without education? }\end{array}$ & $\begin{array}{c}\text { 3. Did education inspire } \\
\text { you? }\end{array}$ \\
\hline Respondent A & Yes & No & Yes \\
Respondent B & Yes & No & Yes \\
Respondent C & Yes & No & Yes \\
\hline
\end{tabular}

The telephone interviews indicate that the three course participants had the advantage of participating in an entrepreneurship education which compelled them to establish new firms.

\subsection{Establishment of New Firms}

Overall results indicate that there is a clear distinction between the firms that have been established by persons who passed the entrepreneurship education (the Respond group) and the firms in the Control group. The firms in the Respond group are for example, much bigger than those in the Control group. Individuals who have passed the entrepreneurship education (the Respond group) have been more likely to establish new firms than those who have not. As Table 4 shows, there are nearly three times more established firms in the Respond group than in the Control group.

Table 4. Established new firms

\begin{tabular}{lcc}
\hline & Number & Percent \\
\hline Respond group & 28 & 36 \\
Control group & 11 & 12 \\
\hline
\end{tabular}

The growth amongst those established new firms in the Respond group is also visible when we, for example, examine the number of employees (Table 5). The total numbers of employees in established new firms increased from 41 to 148 persons (+261 percent) in the firms in the Respond group. The firms in the Control group have no employees at all.

Table 5. Total number of employees in established new firms

\begin{tabular}{lccc}
\hline & $\begin{array}{c}\text { Start up year } \\
\text { (numbers) }\end{array}$ & 2009 (numbers) & Change (percent) \\
\hline Respond group & 41 & 148 & +261 \\
Control group & 0 & 0 & - \\
\hline
\end{tabular}

The total amount of the turnover 2009 in the Respond group was 503251000 Swedish crowns (Skr) (56 545056 euro), which corresponds to a growth of 132 percent from start until 2009 (Table 6). The corresponding turnover in the Control group was $1745000 \mathrm{Skr}$ (196067 euro), which was a reduction of the total turnover by 24 percent. Another interesting development concerning the firms in the Respond group is the reduction of turnover per 
employee. This declined from 5.3 million Skr (596 000 euro) during the start-up year to 3.4 million Skr (382 000 euro) per employee in 2009.

Table 6. Total turnover in established new firms

\begin{tabular}{lccc}
\hline & $\begin{array}{c}\text { Start-up year } \\
\text { (thousands of Skr) }\end{array}$ & $\begin{array}{c}2009 \text { (thousands of } \\
\text { Skr) }\end{array}$ & Change (percent) \\
\hline Respond group & 216130 & 503251 & +132 \\
Control group & 2296 & 1745 & -24 \\
\hline
\end{tabular}

The established new firms in the Respond group are much bigger than those in the Control group and have also had a much more positive growth process than those in the Control group. The establishment of the new firms in the Respond group has strengthened as a result of the growth of the number of employees and the turnover which not is the case among the established firms in the Control group.

\subsection{Entrepreneurial Activity}

The entrepreneurial activity is more salient in the Respond group than in the Control group. As seen above (Table 4) 36 percent of the individuals in the Respondent group have established new firms compared to 12 percent in the Control group. Of those who have passed the entrepreneurship education and have established one firm, there are 22 percent or 8 persons, who also are running two or more firms (Table 7). The corresponding percent for those who not have attended an entrepreneurship education is nought percent.

Table 7. Persons who are running two firms or more (percent)

\begin{tabular}{lcc}
\hline & Number & Percent \\
\hline Respond group & 8 & 22 \\
Control group & 0 & 0 \\
\hline
\end{tabular}

Consequently, individuals in the Respond group are more active in establishing and developing new firms than those in the Control group, in other words the individuals in the respond group show a greater entrepreneurial activity than those in the Control group.

\section{Discussion}

The present study shows that individuals who have attended an entrepreneurship education are more prone to establish firms, to establish several firms, and to create larger firms, as compared to those who have not attended an entrepreneurship education (Control group). From that point of view, it seems that entrepreneurship education matters. The result of the survey also shows that those who have not attended an entrepreneurship education (the Control group) regard the entrepreneurial intentions as an inheritance, unlike to those who have completed an entrepreneurship education (the Respond group) who think that one can create one's destiny by oneself. The telephone interviews show, in addition to this, that there was an entrepreneurial intention amongst the three persons interviewed. They all possessed an intention to establish a firm when they began their entrepreneurship education, which can be closely connected to the definition of entrepreneurial thinking by Johannisson et al., (2000) or the discussion of entrepreneurial intention see $\mathrm{Wu}$ and $\mathrm{Wu}$ (2008); Nabi et al., (2010). Most probably, those who enter an entrepreneurship education have a plan to establish a new firm, and therefore, such an education functions as a 'starter' for those individuals who have this intention.

\section{To summarize:}

The answer on the question "does entrepreneurship education lead to the establishment of new firms?" - can out of the presented results be formulated as yes! But this answer has two parts:

1) First, those who have attended an entrepreneurship education are more prone and show more entrepreneurial activity in establishing new firms and managing them. This is, however, probably dependent on the self-selection bias, i.e., the persons who have attended an entrepreneurship education have selected themselves for the education but with an ambition to establish a firm.

2) Second, an entrepreneurship education functions as a 'starter' for those individuals who have attended an 
entrepreneurship education and had an intention/idea to establish a new firm. This is an important result of the study, namely that those who have an intention to start and run a firm realize this intention as a result of their entrepreneurship education.

Future research addressing why and how an entrepreneurship education can lead to greater entrepreneurial activity is needed. Therefore, my aim is to continue this study with in-depth interviews to catch these possible dimensions. Furthermore, in-depth interviews might also provide deeper insight into individuals' entrepreneurial thinking and their learning processes about becoming entrepreneurs, as a result of their entrepreneurship education.

Another interesting arena for future research is to study similarities between a firm's development process and the process of New Product Development (NPD). A firm's development process (Figure 1) has been described as consisting of three phases: a creative phase, a setting-up phase, and an operational phase. In this context, Ylinenpää (2007, p. 67) writes, "the entrepreneur is seen as a pattern breaking innovator...", and Wallas (1926) similarly writes, "which implies that a firm's development process can be seen as a creative and an innovative process. In the creative phase the business idea can be seen as fuzzy and easy to change and the degree of formalization is often low but the need of creativity is high." In this description, we can see similarities to the process of New Product Development (NPD) and the first phase in that process namely the Fuzzy Front-End (FFE). Kim and Wilemon (2002) discuss the content of the FFE and say that this phase of the NPD is characterised by fuzzy ideas, informal decision-making, and a low degree of formalization. In the same way, it is possible to compare the setting-up phase in a firm's development process to the development phase in the NPD. To study and explore the similarities between the two processes and to explore the possibilities of using experiences from the NPD process in the firm's development process would be an interesting route for future research.

\section{References}

Cox, L. W., Mueller, S. L., \& Moss, S. E. (2002). The impact of entrepreneurship education on entrepreneurial self-efficacy. International Journal of Entrepreneurship Education, 1(1), 229-245.

Dana, L. P. (2001). The education and training of entrepreneurs in Asia. Education + Training, 43(8/9), 405-415. http://dx.doi.org/10.1108/EUM0000000006486

De Faoite, D., Henry, C., Johnston, K., \& van der Sijde, P. (2003). Education and training for entrepreneurs: a consideration of initiatives in Ireland and the Netherlands. Education? Training, 45(8/9), 430-438. http://dx.doi.org/10.1108/00400910310508829

Drucker, P. F. (1985). Innovation and Entrepreneurship. New York: Harper and Row.

Garavan, T., \& O' Cinnéide, B. (1994). Entrepreneurship education and training programmes: a review and evaluation, part I. Journal of European Industrial Training, 18(8), 3-12 http://dx.doi.org/10.1108/03090599410068024

Hansemark, O. C. (1998). The effects of an entrepreneurship programme on Need for Achievement and Locus of Control of reinforcement, Journal of Entrepreneurial Behaviour \& Research, 4(1), 28-50. http://dx.doi.org/10.1108/13552559810203957

Henry, C., Hill, F., \& Leitch, C. (2005). Entrepreneurship education and training: can entrepreneurship be taught? Part II, Education + Training, 47(3), 158-169. http://dx.doi.org/10.1108/00400910510592211

Jack, S. L., \& Anderson, R. (1998). Entrepreneurship education within the condition of entreprenology. Paper presented at the Conference on Enterprise and Learning, Aberdeen.

Johannisson, B., Madsén, T., \& Wallentin, C. (2000). Aha! Företagsamt lärande! Örebro: Ljungföretagen Tryckeri $\mathrm{AB}$.

Kim, J., \& Wilemon, D. (2002). Focusing the fuzzy front-end in new product development. $R \&$ D Management, 32(4), 269-279. http://dx.doi.org/10.1111/1467-9310.00259

Kuratko, D. (2003). Entrepreneurship Education: Emerging Trends and Challenges for the $21^{\text {st }}$ Century. Coleman Foundation White Paper Series. Chicago, IL.

Matlay, M. (2005). Researching entrepreneurship and education. Part 1: What is entrepreneurship and does it matter? Education + Training, 47(8/9), 665-667 http://dx.doi.org/10.1108/00400910510633198

McMullan, W. E., \& Gillin, L. M. (2001). Entrepreneurship education in the nineties. In Brockhaus R. H., Hills G. E., Klandt H., \& Welch H. P. (Eds.), Entrepreneurship Education: A Global View. Aldershot: Ashgate Publishing.

Mitra, J., \& Matlay, H. (2004). Entrepreneurial and vocational education and training: lessons from eastern and 
$\begin{array}{llll}\text { central Europe. Industry and Higher } & \text { Education, 18(1), }\end{array}$ http://dx.doi.org/10.5367/000000004773040979

Nabi, G., Holden, R., \& Walmsley, A. (2010). Entrepreneurial intentions among students: towards a re-focused research agenda. Journal of Small Business and Enterprise Development, 17(4), 537-551. http://dx.doi.org/10.1108/14626001011088714

Nilsson, TB. (1997). Custom-oriented action in small manufacturing firms - case studies of three firms (Kundagerande i små tillverkande företag. Fallstudier av tre företag), $\mathrm{PhD}$ thesis 1997:30 Luleå University of Technology, 236-237, Sweden.

Robinson, P. B., Stimpson, D. V., Huefner, J. C., \& Hunt, H. K. (1991). An attitude approach to the prediction of entrepreneurship. Entrepreneurship Theory and Practice, 15(4), 13-31.

Souitaris, V., Zerbinati, S., \& Al-Lahman, A. (2007). Do entrepreneurship programmes raise entrepreneurial intention of science and engineering students? The effect of learning, inspiration and resources. Journal of Business Venturing, 22(4), 566-591. http://dx.doi.org/10.1016/j.jbusvent.2006.05.002

Wallas, G. (1926). The Art of Thought. New York: Harcourt Brace and Company.

$\mathrm{Wu}, \mathrm{S} .$, \& Wu, L. (2008). The impact of higher education on entrepreneurial intentions of university students in China. Journal of Small Business and Enterprise Development, 15(4) 752-774. http://dx.doi.org/10.1108/14626000810917843

Ylinenpää, H. (2007). Innovationssystem ur ett aktörsperspektiv. Nätverk och entreprenörer. In S. Laestadius, C. Nuur, \& H. Ylinenpää (Eds.), Regional växtkraft $i$ en global ekonomi (p. 57-75). Stockholm: Santérus Academic Press.

\section{Selected Journals}

Education + Training (2006-2011) Volume 48-53

Entrepreneurship Theory and Practice (2006-2011) Volume 30-35)

Journal of Business Venturing (2006-2011) Volume 21-26

Journal of Small Business and Enterprise Development (2006-2011) Volume 13-18

Journal of Small Business Management (2006-2011) Volume 44-49 